Bangladesh J. Bot. 36(1): 81-83, 2007 (June)

- Short communication

\title{
NEURYMENIA FRAXINIFOLIA (MERT.) J. AG. - A NEW RECORD OF A MARINE RED ALGA FOR BANGLADESH
}

\author{
Abdullah Harun Chowdhury ${ }^{*}$ and Roxana Ahmed ${ }^{1}$ \\ Environmental Science Discipline, Khulna University, Khulna-9208, Bangladesh \\ Key words: Neurymenia fraxinifolia, Marine red alga, New record, Bangladesh
}

\begin{abstract}
Neurymenia fraxinifolia (Mert.) J. Ag. a marine red alga has been described and illustrated for the first time from St. Martin's Island, Bangladesh.

The algal sample was collected during low tide attached to inside black rocky hole in the northern side of 'Boroshiler Bandh' area of west coast of St. Martin's Island, Bangladesh on 14 February, 2006. The alga has been identified as Neurymenia fraxinifolia (Mert.) J. Ag. (Srinivasan 1969). The samples of $N$. fraxinifolia were preserved in $5 \%$ formalin in the sea water and kept in Environmental Science Discipline, Khulna University, Khulna-9208, Bangladesh.

Islam (1976) described 49 taxa of marine red algae under 35 genera from Bangladesh. Later on more marine red algae from this island were reported (Aziz (1997, Aziz et al. (2002a, 2002b, Islam and Aziz 1982, 1987, Islam et al. 2002). N. fraxinifolia (Mert.) J. Ag. is being reported here for the first time from Bangladesh.

Detailed description and illustrations are given on the basis of fresh and preserved materials.

\section{Class: Rhodophyceae, Order: Ceramiales, Family: Rhodomelaceae}

Neurymenia fraxinifolia (Mert.) J. Ag.

(Figs. 1-4) (Srinivasan 1969).

Colour of the thallus deep-red to purplish, becomes reddish-brown on drying. Fronds simple linear oblong, membranous, lamina in older plants decayed and the midrib serves as a stipe. Fronds, $8-15 \mathrm{~cm}$ or more long, obtuse at base, rounded at apices, undulated and serrated throughout. Adventitious branches develop from the midrib of older lamina. Veins with short proliferations arising from both surfaces of lamina. Frond margins spinose with subulate and recurved ramuli; similar processes arising from veins and midrib also. Stem cylindrical, simple or branched thickened and denuded. Fructifications in secondary adventitious branchlets. Stichidia elongated, ovate or oblong, apex rounded, shortly stipitate, containing double rows of tetrasporangia. Tetrasporangia $80-100 \mu \mathrm{m}$ long, 60 - $70 \mu \mathrm{m}$ broad. Spermatangia cylindrical, $100-130 \mu \mathrm{m}$ in diameter. Carposporophyte obovate, urn-shaped, 50 - $65 \mu \mathrm{m}$ broad, 55 - $75 \mu \mathrm{m}$ long and solitary.
\end{abstract}

\footnotetext{
*Corresponding author. E-mail: <aharunc@yahoo.co.uk> ${ }^{1}$ Part time teacher of Botany, Soil Science Discipline, Khulna University, Khulna-9208, Bangladesh.
} 
The alga is an inhabitant of deep water (ca. 8-10 m) and well protected by rocks at St. Martin's Island. It grows forming an interesting community on the vertical faces or inwardly scooped out portions of black rocks, which are only strongly agitated by the swell and swift currents.
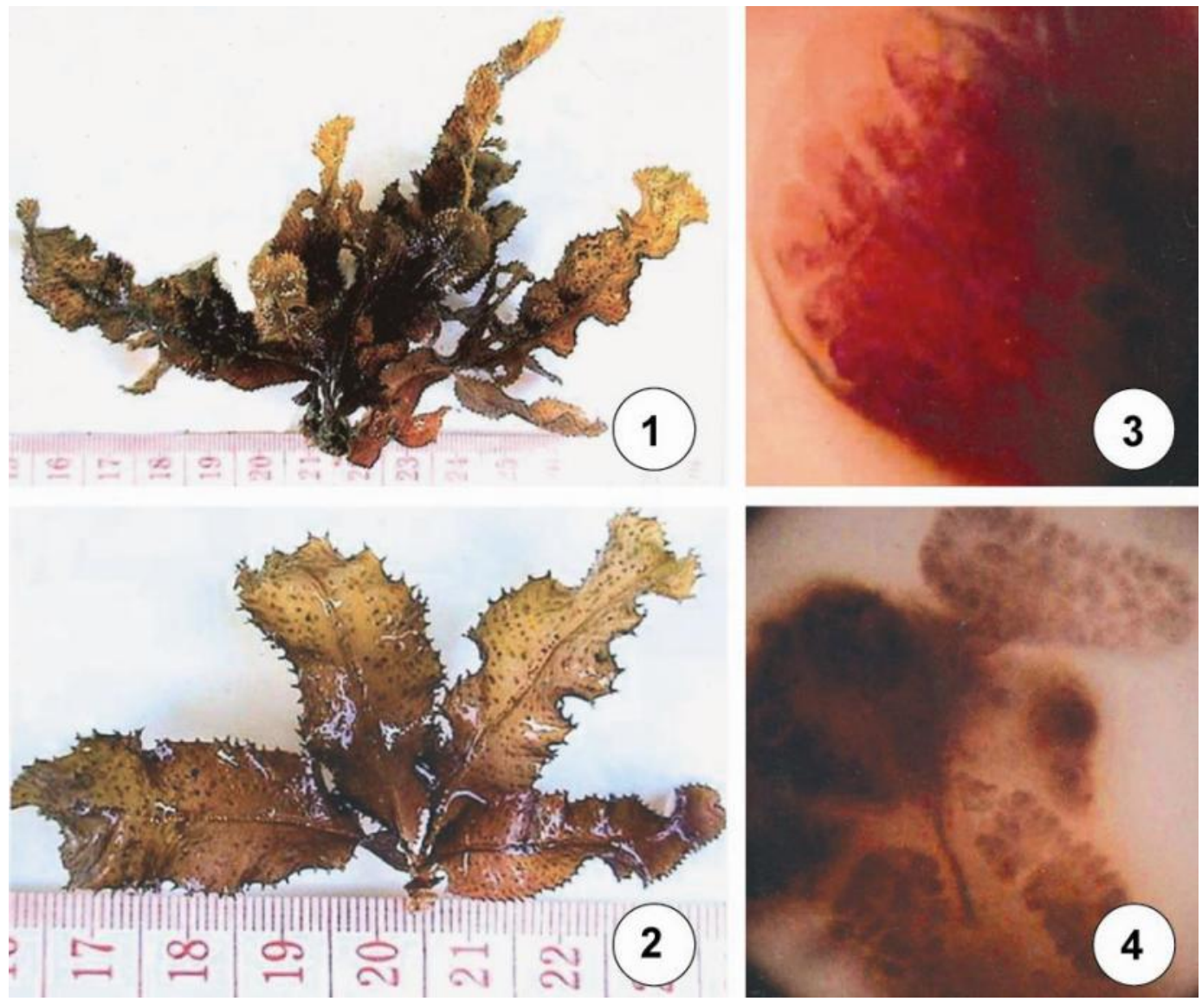

Figs. 1-4: Neurymenia fraxinifolia (Mert.) J.Ag. 1-2. Whole plants. 3. A carposporophyte enlarged. 4. Spermatangial seri.

Distribution: Kenya, Madagascar, Mauritius, Mozambique, South Africa, Indonesia and Sri Lanka (Silva et al.1996); Réunion, Tanzania (Oliveira et al. 2005); Philippines (Kraft et al. 1999); India (Sahoo et al. 2001); Japan (Yoshida 1998); Taiwan (Huang 2000); Australia and New Zealand: Papua New Guinea (Huisman 2000, Littler and Littler 2003); Fiji (South and Skelton 2003).

\section{Acknowledgement}

The authors are thankful to the authority of the St. Martin's Project, Ministry of Environment and Forest, for providing necessary support during the collection of samples. 


\section{References}

Aziz, A. 1997. Peyssonnelia polymorpha (Zonara.) Schmitz (Rhodophyta) newly recorded from St. Martin's Island, Bangladesh. Bangladesh J. Plant Taxon. 4(1): 81-83.

Aziz, A., A.K.M. Nurul Islam and A. Jahan. 2002a. Marine algae of St. Martin's Island, Bangladesh. III. Red algae. J. Asiat. Soc. Bangladesh 28(1): 63-70.

Aziz, A., A.K.M. Nurul Islam and A. Jahan. 2002b. Marine algae of St. Martin's Island, Bangladesh. IV. New records of red algae. Bangladesh J. Bot. 31(2): 113-116.

Huang, S.F. 2000. Seaweeds of Northeastern Taiwan. National Taiwan Museum, Taipei. Vol. 12: 233.

Huisman, J.M. 2000. Marine Plants of Australia. University of Western Australia Press, Nedlands, Western Australia. 300+9 pp.

Islam, A.K.M. Nurul and A. Aziz.1982. Addition to the list of marine algae of St. Martin's Island, Bangladesh. II. Brown, red and blue-green algae. Nova Hedwig. 36: 643-657.

Islam, A.K.M. Nurul and A. Aziz. 1987. Addition to the list of marine algae from St. Martin's Island, Bangladesh. III. Red algae. Nova Hedwig. 45(1-2): 211-221.

Islam, A.K.N. Nurul, A. Aziz and A. Jahan. 2002. Marine algae of St. Martin's Island, Bangladesh II. New records of red algae. Bangladesh J. Bot. 31(1): 23-29.

Islam, A.K.M. Nurul.1976. Contribution to the study of the benthic marine algae of Bangladesh. Bibl. Phycol. 19:1-253.

Kraft, G.T., L.M. Liao, A.J.K. Millar, E.G.G. Coppejans, M.H. Hommersand and D.F. Wilson. 1999. Marine benthic red algae (Rhodophyta) from Bulusan, Sorsogon Province, Southern Luzon, Philippines. The Philippine Scientist 36: 1-50.

Littler, D.S., and M.M. Littler. 2003. South Pacific Reef Plants. A diver's guide to the plant life of the South Pacific Coral Reefs. Off Shore Graphics, Inc. Washington DC. 331 pp.

Oliveira, E., K. Österlund and M.S.P. Mtolera. 2005. Marine Plants of Tanzania. A field guide to the seaweeds and seagrasses- Numerous coloured illustrations and line drawings. Bot. Dept., Stockholm Univ., Stockholm. 267 pp.

Sahoo, D., Nivedita and Debasish. 2001. Seaweeds of Indian coast. A.P.H. Publishing, New Delhi. 283+21 pp.

Silva, P.C., P.W. Basson and R.L. Moe. 1996. Catalogue of the benthic marine algae of the Indian Ocean. Univ. California Publications Bot. 79: 1-1259.

South, G.R. and P. A. Skelton. 2003. Catalogue of the marine benthic macroalgae of the Fiji Islands, South Pacific. Australian Systematic Botany 16: 699-758.

Srinivasan, K.S. 1969. Phycologia Indica: Icones of Indian Marine Algae. Botanical Survey of India. Vol. 1, 52 pp.

Yoshida, T. 1998. Marine algae of Japan. Uchida Rokakuho Publishing, Tokyo. $1222+25$ pp. 